\title{
Prêt-à-ratifier: The CETA Decision of the French Conseil constitutionnel of 31 July 2017
}

\author{
Joris Larik*
}

\section{INTRODUCTION}

The Comprehensive Economic and Trade Agreement (CETA; in French Accord économique et commercial global) has been advertised as the 'gold standard' 1 of the EU's new generation of free trade agreements. CETA is a 'mixed agreement', i.e., its parties are the EU and its Member States, on the one side, and Canada, on the other. This combination of ambitious content that goes far beyond classic trade issues such as tariffs, plus its mixed nature make this a fertile ground for a plethora of legal and political controversies. CETA, moreover, has been drawn all the more into the spotlight since the Transatlantic Trade and Investment Partnership with the United States was put on hold for the foreseeable future.

A range of the controversial issues surrounding CETA found their way before the French Conseil constitutionnel (Constitutional Council), ${ }^{2}$ the country's highest authority on constitutional matters. On 31 July 2017, it handed down its decision,

*Assistant Professor at Leiden University; Senior Researcher at The Hague Institute for Global Justice; and Associate Fellow at the Leuven Centre for Global Governance Studies. This case note was written while the author was a visiting research fellow at the Center for Transatlantic Relations at the Paul H. Nitze School of Advanced International Studies of Johns Hopkins University in Washington, D.C., funded by a Fulbright-Schuman Scholar Grant.

${ }^{1}$ European Commission, Joint statement: Canada-EU Comprehensive Economic and Trade Agreement (CETA), STATEMENT/16/446, Brussels, 29 February 2016. For an opposing view from an environmental non-governmental organisation, see Client Earth and Transport \& Environment, Comprehensive Economic and Trade Agreement (CETA) and the environment: A gold standard for the planet or for big business? (November 2016), available at <www.transport environment.org/sites/te/files/publications/2016_11_CETA_Gold_Standard_FINAL.pdf> visited 12 October 2017.

${ }^{2}$ To avoid confusion, throughout this case note, the terms Conseil constitutionnel and Conseil will be used to refer to the French Constitutional Council, whereas Council will refer to the Council of the European Union. 
concluding that there was nothing in CETA that was at odds with French constitutional law. ${ }^{3}$ It was the first national court to reach a substantive judgment on whether CETA was compatible with a Member State's constitution. On 13 October 2016, the German Bundesverfassungsgericht (Federal Constitutional Court) had already ruled on a request for interim measures (einstweilige Anordnung), which it rejected. ${ }^{4}$ Only a few weeks prior to the Conseil constitutionnel's decision, the European Court of Justice delivered a seminal opinion on the EU-Singapore Free Trade Agreement, which clarified the mixed nature of the agreement and the extent of the EU's exclusive competences within the areas it covered, ${ }^{5}$ thus becoming an important point of reference for the judicial scrutiny of CETA and EU trade agreements in general. CETA will also be subject to ex ante review at the European Court of Justice, as Belgium requested an opinion on the compatibility of the agreement's investment chapter with the EU Treaties on 6 September $2017 .^{6}$ Thus, while the Conseil constitutionnel's decision is another milestone in the judicial saga surrounding CETA, it is certainly not the end of the road.

In its reasoning rejecting the complaints against CETA, the Conseil employed a dynamic and cooperative interpretation of sovereignty and showed a strong attitude of deference both to France's political branches and to the EU in terms of international treaty-making. There are, however, some aspects where the decision would have benefited from greater clarity. Nonetheless, instead of undermining France's constitutional order, the Conseil confirmed the fundamental commitment of France to European integration and international cooperation. More particularly, it refrained from unduly interfering with the ability of the EU and its Member States to continue operating as a collective international actor. Following a brief exposition of the background of the case and a summary of the Conseil's decision, the case note elaborates on why despite some shortcomings, its CETA decision is to be welcomed.

\footnotetext{
${ }^{3}$ Conseil constitutionnel 31 July 2017, Décision $\mathrm{n}^{\circ}$ 2017-749 DC, Accord économique et commercial global entre le Canada, d'une part, et l'Union européenne et ses États membres, d'autre part, ECLI:FR:CC:2017:2017.749.DC. Translations of parts of the decision used in this case note were prepared by the author. An English translation was not provided on the website of the Conseil constitutionnel at the time of writing.

${ }^{4}$ Bundesverfassungsgericht 13 October 2016, Urteil des Zweiten Senats, 2 BvR 1368/16, ECLI: DE:BVerfG:2016:rs20161013.2bvr136816. See, for commentary, R.T. Hoffmann, 'Das CETAUrteil des Bundesverfassungsgerichts - Nach der Unterzeichnung ist vor der Ratifikation', 19 Zeitschrift für Europarechtliche Studien (ZEuS) (2016) p. 459. A decision on the merits is yet to follow at the time this case note was written.

${ }^{5}$ ECJ 16 May 2017, Opinion 2/15, ECLI:EU:C:2017:376, EU-Singapore FTA.

${ }^{6}$ The procedure used here is established in Art. 218(11) TFEU. See Kingdom of Belgium, Minister Reynders submits request for opinion on CETA, 6 September 2017, available at <https:// diplomatie.belgium.be/en/newsroom/news/2017/minister_reynders_submits_request_opinion_ceta> visited 12 October 2017.
} 


\section{BACKGROUND}

The request for a ruling on constitutional compatibility by the Conseil constitutionnel was made on 22 February 2017 by a group of 106 left-wing members of the French Assemblée nationale (National Assembly). ${ }^{7}$ The members of parliament availed themselves of Article 54 of the French Constitution, according to which France cannot ratify an international agreement which in the eyes of the Conseil constitutionnel contains provisions incompatible with French constitutional law, unless the Constitution is amended beforehand. Such a request for an a priori review can be requested by the President of the Republic, the Prime Minister, the President of either of the chambers of parliament or, as was the case here, by a group of 60 or more members of either chamber of the legislature. ${ }^{8}$

The request and the decision are two more points on an already long and eventful timeline regarding CETA's negotiation and ratification process. To briefly recapitulate, the main negotiations for CETA were launched in May 2009 and concluded in August 2014. In February 2016, the legal review of the text was completed, which included important amendments including a revised investment protection chapter reflecting the EU's 'new approach', to assuage concerns about traditional ad hoc arbitration, including, among other measures, an appellate mechanism and 'more detailed commitments on ethics for all tribunal members' as part of a what is called the 'Investment Court System'. In July 2016, the European Commission declared that CETA should, for political reasons, be a mixed agreement. ${ }^{10}$ In October 2016, the signing of CETA was put in jeopardy by the refusal of the regional parliament of the Belgian state of Wallonia to lend its consent, which was required under Belgian constitutional law. ${ }^{11}$ In an effort to save the agreement without reopening the text, on 27 October 2016 a Joint Interpretative Instrument was adopted which further clarified some of the contentious points. ${ }^{12}$

\footnotetext{
7 ‘Ceta: 106 députés saisissent le Conseil constitutionnel’, Le Figaro, 21 February 2017, <www. lefigaro.fr/flash-eco/2017/02/21/97002-20170221FILWWW00324-ceta-106-deputes-saisissent-leconseil-constitutionnel.php> visited 12 October 2017.

${ }^{8}$ The possibility for a group of 60 members of parliament to request an Art. 54 review was only added by virtue of a constitutional amendment in 1992: J.-P. Jacqué, Droit constitutionnel et institutions politiques (11th edn, Dalloz 2016) p. 243.

${ }^{9}$ European Commission, supra n. 1.

${ }^{10}$ European Commission, European Commission proposes signature and conclusion of EU-Canada trade deal, Press Release, 5 July 2016, <europa.eu/rapid/press-release_IP-16-2371_en.htm> visited 12 October 2017.

${ }^{11}$ See 'David vs Goliath? Small Belgium region leaves EU-Canada trade deal in crisis', France24, 22 October 2016, <www.france24.com/en/20161021-eu-canada-trade-deal-ceta-collapses-belgianregion-wallonia-refuses-sign $>$ visited 12 October 2017.

${ }^{12}$ Joint Interpretative Instrument on the Comprehensive Economic and Trade Agreement (CETA) between Canada and the European Union and its Member States, Brussels, 27 October 2016, 13541/16.
} 
The latest steps were the signing of the agreement on 30 October $2016,{ }^{13}$ its approval by the European Parliament on 15 February 2017, ${ }^{14}$ and the decision to provisionally apply those parts of CETA which fall under the EU's exclusive competence from 21 September 2017. ${ }^{15}$ The still controversial Investment Court System is not part of the provisional application. ${ }^{16}$

The requesting members of the Assemblée Nationale made a range of complaints in their request for a compatibility review by the Conseil constitutionnel that can be summarised as follows: First, that CETA introduces obligations which constrain domestic rulemaking in such a way that it would affect the essential conditions for the exercise of France's national sovereignty (conditions essentielles d'exercice de la souveraineté nationale). In particular, they took issue with CETA's chapter on investment protection as infringing basic principles of the rule of law, noting, furthermore, that the agreement would violate the precautionary principle, which has constitutional status in France. ${ }^{17}$ In addition, they contended that CETA's provisions on its provisional application as well as on its termination were unconstitutional. ${ }^{18}$

The stakes of this decision were high. One the one hand, once given the judicial green light and ratified, a 'treaty enjoys constitutional immunity' in France, which means that 'the Conseil constitutionnel will not review its constitutionality at a later stage. ${ }^{19}$ On the other hand, a negative ruling would

${ }^{13}$ Council Decision (EU) 2017/37 of 28 October 2016 on the signing on behalf of the European Union of the Comprehensive Economic and Trade Agreement (CETA) between Canada, of the one part, and the European Union and its Member States, of the other part [2017] OJ L 11/1.

${ }^{14}$ European Parliament legislative resolution of 15 February 2017 on the draft Council decision on the conclusion of the Comprehensive Economic and Trade Agreement (CETA) between Canada, of the one part, and the European Union and its Member States, of the other part (10975/2016 C8-0438/2016 - 2016/0205(NLE)).

${ }^{15}$ Council Decision (EU) 2017/38 of 28 October 2016 on the provisional application of the Comprehensive Economic and Trade Agreement (CETA) between Canada, of the one part, and the European Union and its Member States, of the other part [2017] OJ L 11/1080. The exact date was determined later on and jointly proclaimed by Commission President Juncker and Prime Minister Trudeau, see European Commission, EU and Canada agree to set a date for the provisional application of the Comprehensive Economic and Trade Agreement, STATEMENT/17/1959, Brussels, 8 July 2017.

${ }^{16}$ Council Decision (EU) 2017/38, supra n. 15, Art. 1(a), which lists those parts of the investment chapter that will be provisionally applied. It does not include Arts. 8.18-8.45 of CETA, which make up Section F on the "Resolution of investment disputes between investors and states".

${ }^{17}$ Charte de l'environnement, Art. 5.

${ }^{18} \mathrm{See}$ for the full request by the members of parliament Conseil constitutionnel, Saisine par 60 députés - 2017-749 DC, Paris 22 February 2017, <www.conseil-constitutionnel.fr/conseilconstitutionnel/francais/les-decisions/acces-par-date/decisions-depuis-1959/2017/2017-749-dc/ saisine-par-60-deputes. 149545. html > visited 12 October 2017.

${ }^{19}$ M. Claes, The National Courts' Mandate in the European Constitution (Hart 2006) p. 469-470. 
put another spanner in the works for the ratification of CETA, and more importantly, confirm the scepticism of its detractors that the new generation of Free Trade Agreements (if not all such Agreements) are vehicles of multinational corporations to erode the state's regulatory powers, democratic checks, and hard-won labour and environmental standards. It is doubtful whether CETA would have recovered from such a setback, given that the 'Wallonia crisis' of late 2016 preceding its signing had already come close to exhausting the political capital between the two parties. As Canada's then Trade Minister Chrystia Freeland put it at the height of the crisis: 'It seems evident for me and for Canada that the European Union is not now capable of having an international accord even with a country that has values as European as Canada'. ${ }^{20}$ Being branded unconstitutional by a national court of last instance would all but have cemented this incapacity.

\section{The Decision of the Conseil constitutionnel}

The Conseil constitutionnel rejected all complaints brought forward by the group of parliamentarians, after first summarising the content of CETA and its complementary materials, and clarifying the two standards of review it would apply to different areas of the agreement.

Regarding the latter point, the Conseil recalled that French constitutional law consists of more than just the text of the current constitution (the 1958 Constitution of the Fifth Republic). It encompasses an ensemble of norms that French scholarship calls the bloc de constitutionnalité. ${ }^{21}$ These include also the 1789 Declaration of the Rights of Man and of the Citizen, the preamble of the 1946 Constitution of the Fourth Republic, the Environmental Charter of 2004 (Charte de l'environnement), fundamental principles recognised by the laws of the Republic (les principes fondamentaux reconnus par les lois de la République), constitutional objectives (objectifs de valeur constitutionnelle), and a number of other general principles. ${ }^{22}$ The Conseil stressed also France's commitment to take part in the European Union, enshrined in Article 88-1 of the constitution, noting that the constitutional legislator (constituant) has thus explicitly acknowledged 'the existence of a legal order of the European Union

\footnotetext{
${ }^{20}$ As cited in S. Amaro, 'EU trade policy remains at risk despite Belgium support for EU-Canada deal', CNBC, 27 October 2016, <www.cnbc.com/2016/10/27/eu-trade-policy-remains-at-riskdespite-belgium-support-for-eu-canada-deal.html> visited 12 October 2017.

${ }^{21}$ See D. Rousseau, Droit du contentieux constitutionnel (8th edn, Montchrestien 2008) p. 101-112; and Jacqué, supra n. 8, p. 165-167.

${ }^{22}$ The preamble of the Constitution of the Fifth Republic references the 1789 Declaration, the preamble of the Constitution of the Fourth Republic and the 2004 Environmental Charter.
} 
integrated into the domestic legal order and distinct from the international legal order. ${ }^{23}$

Subsequently, the Conseil constitutionnel stressed the importance of distinguishing between matters of, on the one hand, exclusive EU competence covered in the agreement, and matters of non-exclusive competence (shared and those solely within the competence of the Member States), on the other. Depending on whether a particular provision falls into one or the other category, different standards of review apply. For matters of shared competence, the Conseil checks for incompatibilities with all norms of French constitutional law. ${ }^{24}$ For matters falling within the EU's exclusive competence, the Conseil applies a more narrow review of the envisaged agreement's provisions, i.e., 'to ensure that they do not challenge a rule or a principle inherent to the constitutional identity of France. ${ }^{25}$ Apart from that, the Council noted that it will be for the European Court of Justice alone to check the compatibility of the agreement with EU law. ${ }^{26}$

In terms of the distinction between exclusive EU competences and shared competences, the Conseil drew explicitly on the European Court of Justice's Opinion 2/15 on the EU-Singapore Free Trade Agreement. ${ }^{27}$ The Council explained that the parts of CETA's Chapter 8 that applied to non-direct investment and its Section F on investor-state dispute settlement did not fall within the EU's exclusive competence. In addition, the same applied to certain - often cross-cutting or generally applicable - provisions in chapters 1 (General Definition and Initial Provisions), 21 (Regulatory Cooperation), 26 (Administrative and Institutional Provisions), 27 (Transparency), 28 (Exceptions), 29 (Dispute Settlement) and 30 (Final Provisions) to the extent that they related to matters of shared competence. ${ }^{28}$ Having set out these parameters, the Council then spent the main part of the decision assessing the constitutional complaints - first for the chapter on investment and subsequently for the other shared provisions - before turning to the other provisions and delivering its overall conclusion.

Regarding Chapter 8 on investment, the Conseil constitutionnel addressed the complaints regarding excessive constraints on the exercise of national sovereignty, the principles of judicial independence and impartiality, equality before the law, as

\footnotetext{
${ }^{23}$ Conseil constitutionnel 31 July 2017, supra n. 3, para. 9 (in the original: 'l'existence d'un ordre juridique de l'Union européenne intégré à l'ordre juridique interne et distinct de l'ordre juridique international').

${ }^{24}$ Ibid., para. 13.

${ }^{25}$ Ibid., para. 14 (in the original: 'de veiller à ce qu'elles ne mettent pas en cause une règle ou un principe inhérent à l'identité constitutionnelle de la France').

${ }^{26}$ Ibid., para. 14.

${ }^{27}$ EU-Singapore FTA, supra n. 5.

${ }^{28}$ Conseil constitutionnel 31 July 2017, supra n. 3, para. 17.
} 
well as making a brief reference to the precautionary principle, which is discussed in detail later on in the decision. A complaint about CETA's compatibility with other international agreements and EU law was summarily rejected by the Conseil as falling outside the scope of an Article 54 request, which can only be about compatibility with French constitutional law. ${ }^{29}$

The Conseil constitutionnel rejected the contention that the essential conditions for the exercise of national sovereignty would be hampered by CETA's investment chapter. In its reasoning, the Conseil stressed that investment protection must be seen in the context of removing barriers to free trade between the parties. ${ }^{30}$ Moreover, it underlined that according to CETA's provisions, the tribunal (including its appellate mechanism) set up for adjudicating disputes in this area only has the power to award monetary damages, applicable interest, and restitution of property, ${ }^{31}$ as well as to issue interim measures. ${ }^{32}$ By contrast, the Conseil noted that the Investment Court System would have 'no power of interpretation or annulment of decisions taken by the organs of the European Union or of the Member States'. ${ }^{33}$

The Conseil moreover emphasised the equal input by the EU and Canada regarding the appointment of members of the tribunal and the appellate tribunal, ${ }^{34}$ the professional requirements to serve on these tribunals, ${ }^{35}$ and the 'fork in the road' provision of Article 8.22 CETA, according to which investors are barred from using parallel procedures before domestic courts in case they avail themselves of the Investment Court System under CETA. ${ }^{36}$ Taken together with the Conseil's subsequent reasoning on CETA's recognition of the parties' 'right to regulate', ${ }^{37}$ it concluded that CETA does not disregard the essential conditions for the exercise of France's national sovereignty.

Furthermore, the Council rejected the complaint that Chapter 8 would violate the principles of judicial independence and impartiality. In reaching this conclusion, the Conseil stressed the ethics rules contained in Article 8.30 CETA, which explicitly address the independence of the members of the tribunal and appellate tribunal and include procedures to maintain such independence. ${ }^{38}$

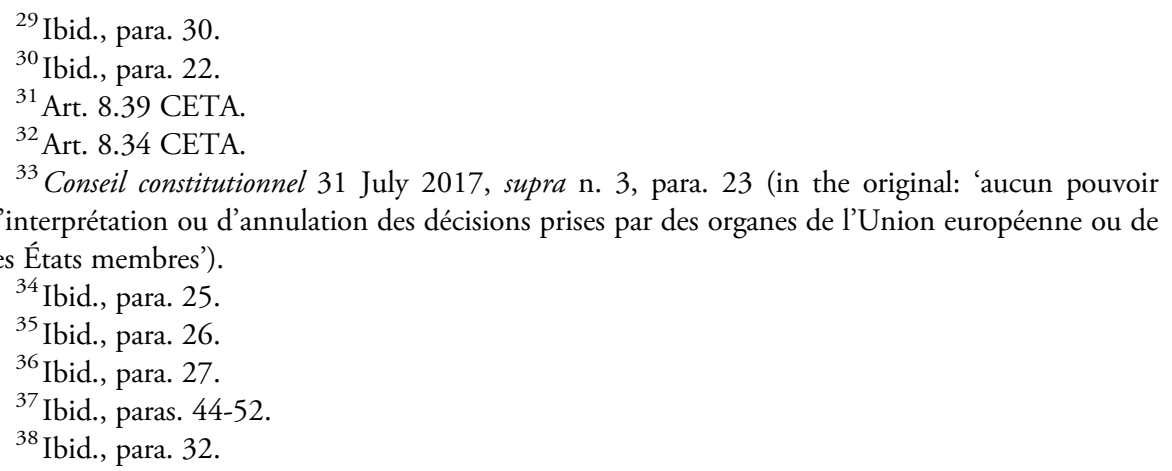


Moreover, the Council noted that the members of the tribunal are nominated for a term of five years, renewable once. ${ }^{39}$ For the Conseil, these provisions were sufficient to avoid any breach of constitutionally-guaranteed principles of independence and impartiality.

Lastly, the Conseil equally rejected the complaint that ratifying CETA would lead to infringing the principle of equality before the law. ${ }^{40}$ In its interpretation, that principle does not preclude regulating different situations differently or derogating from equality on grounds of public interest, provided that the difference in treatment resulting from it is directly related to the object of the law establishing it. ${ }^{41}$

In terms of substance, the Conseil constitutionnel ruled that the very aim of the chapter on investment is to ensure equal treatment of both domestic and foreign investors. This is also highlighted in the Joint Interpretative Instrument, which notes that: 'CETA will not result in foreign investors being treated more favourably than domestic investors. ${ }^{42}$ In terms of procedure, by contrast, the Conseil acknowledged that Section F of Chapter 8 on investor-state dispute settlement would create a special remedy only available to Canadian investors in France. ${ }^{43}$ However, the Conseil considered this difference in treatment justified as it would directly serve the main objective of CETA, i.e., creating on a reciprocal basis a protective framework for French (and other EU) investors in Canada and, vice versa, for attracting Canadian investments in France. ${ }^{44}$ In a somewhat oddly positioned afterthought to this section, the Council also noted that given the subsequent reasoning in its decision, the provisions of Chapter 8 also did not violate the precautionary principle. ${ }^{45}$

In the second main part of the decision, the Conseil constitutionnel turned to the other provisions pertaining to areas of shared competence contained in CETA. Starting again with the complaint of constraining the essential conditions of the exercise of national sovereignty, the Conseil did not find any basis in these parts of CETA either. In particular, it rejected the arguments premised on France's capability to legislate and regulate being constrained by CETA. Under the French constitution, ratified treaties rank above secondary legislation. ${ }^{46}$ However, the

\footnotetext{
${ }^{39}$ Ibid., para. 33.

${ }^{40}$ This principle is enshrined in Art. 6 of the 1789 Declaration of the Rights of Man and of the Citizen.

${ }^{41}$ Conseil constitutionnel 31 July 2017, supra n. 3, para. 35.

${ }^{42}$ Joint Interpretative Instrument, supra n. 12, para. 6 a); Conseil constitutionnel 31 July 2017, supra n. 3, para. 36.

${ }^{43}$ Conseil constitutionnel 31 July 2017, supra n. 3, paras. 37-38.

${ }^{44}$ Ibid., 38.

${ }^{45}$ Ibid., para. 41, referring to paras. 56-59 of the decision.

${ }^{46}$ French Constitution, Art. 55.
} 
Conseil did not see this as problematic in the case of CETA given the assurances it provides to preserve the parties' right to legislate and regulate in the pursuit of legitimate objectives of public policy. It referred here specifically to Article 8.9 CETA and the Joint Interpretative Statement, which reiterates the importance of this right. ${ }^{47}$ Moreover, it observed that prohibitions of certain measures regarding foreign direct investment lie within the exclusive competence of the $\mathrm{EU},{ }^{48}$ implying that they fall outside of the scope of regular constitutional review by the Conseil. Nonetheless, it noted that even there, certain measures are explicitly allowed, such as those aimed at ensuring fair competition and on the conservation and protection of natural resources. ${ }^{49}$ In addition, regarding the provisions on advancing regulatory cooperation contained in CETA, it stressed that these were to be undertaken on a purely voluntary basis. ${ }^{50}$

The Conseil constitutionnel emphasised in this context the role of the Joint Committee established by CETA. It can adopt interpretations of the agreement that bind the tribunals and decisions that bind the parties. The parties thus retain ultimate control over CETA and how it should be interpreted. This control is exercised jointly, i.e. by 'mutual consent ${ }^{51}$ between the parties. Seeing that this is a mixed agreement, the Conseil also noted that while the EU's position would be established by the Council of the $\mathrm{EU},{ }^{52}$ such a position would require the 'common accord' of both the EU and the Member States in case Member State competences are concerned according to the Declaration of the Council and Member States of 14 January 2017. ${ }^{53}$ This means that not only the EU, but also France would retain control whenever non-exclusive competences are at stake. In a similar vein, the Conseil observed that the inter-party dispute settlement mechanism established in Chapter 29 of CETA only serves to ensure compliance with the agreement and in no way affects the rule-making process at the domestic level. $^{54}$

Subsequently, the Conseil constitutionnel rejected the complaint that CETA would violate the precautionary principle enshrined in Article 5 of the Charte

${ }^{47}$ Joint Interpretative Instrument, supra n. 12, para. 2.

${ }^{48}$ Conseil constitutionnel 31 July 2017, supra n. 3, para. 46.

${ }^{49}$ Ibid., para. 46, referring to Art. 8.4, para. 2 CETA.

${ }^{50}$ Conseil constitutionnel 31 July 2017, supra n. 3, para. 47, referring to Art. 21.2, para. 6 CETA, and reiterated in the Joint Interpretative Statement, para. 3.

${ }^{51}$ Conseil constitutionnel 31 July 2017, supra n. 3, para. 50, referring to Art. 26.3, para. 3 CETA.

${ }^{52}$ Art. 218, para. 9 TFEU.

${ }^{53}$ Conseil constitutionnel 31 July 2017, supra n. 3, para. 50. The Declaration of the Council and the Member States is included in Council of the European Union, Comprehensive Economic and Trade Agreement (CETA) between Canada, of the one part, and the European Union and its Member States, of the other part - Statements to the Council minutes, Brussels, 27 October 2016, 13463/1/16 REV 1, No. 19, p. 14.

${ }^{54}$ Conseil constitutionnel 31 July 2017, supra n. 3, para. 52. 
de l'environnement. While the requesting members of parliament criticised the absence of any direct reference to the principle in the text of CETA, the Conseil pointed to Chapter 22 on trade and sustainable development and observed that absence of an explicit reference does not automatically amount to a violation of the principle. ${ }^{55}$ Moreover, it stressed that the precautionary principle is specifically protected within the EU by virtue of Article 191 TFEU. ${ }^{56}$ In addition, the Conseil noted that CETA specifically authorises the use of economically efficient measures to prevent environmental degradation where there is a risk of serious and irreversible damage. ${ }^{57}$ The Conseil also referred again to the Joint Interpretative Statement, which stresses the importance of environmental protection and the parties' right to define their own environmental priorities and policies. ${ }^{58}$

Regarding the provisional application of CETA, the Conseil rejected the complaint that the agreement would leave the matter unsettled of whether the Member States could terminate CETA's provisional application and thus constrain the exercise of their sovereignty. In its assessment, the Conseil referred to the decision of the Council of the EU of 28 October 2016, in which it was established that those parts of CETA which fell outside the exclusive competence of the EU would not be the subject of its provisional application. ${ }^{59}$ In addition, it pointed to the Declaration of 14 January of the Council, in which it was established that if the ratification process for CETA ultimately failed due to constitutional obstacles, including due to a ruling by a constitutional court, and following an official notification of this by the Member State in question, CETA's provisional application would be halted. ${ }^{60}$

Lastly, concerning termination of the agreement, the Conseil constitutionnel addressed the complaint that CETA would 'irrevocably bind France', ${ }^{61}$ which in turn would also constrain the essential conditions for the exercise of its national sovereignty. The Conseil rejected the premise of this complaint, observing that the provisions on termination contained in CETA made it clear that parties would not be bound in perpetuity. ${ }^{62}$ Moreover, the Council noted that, with a view to its

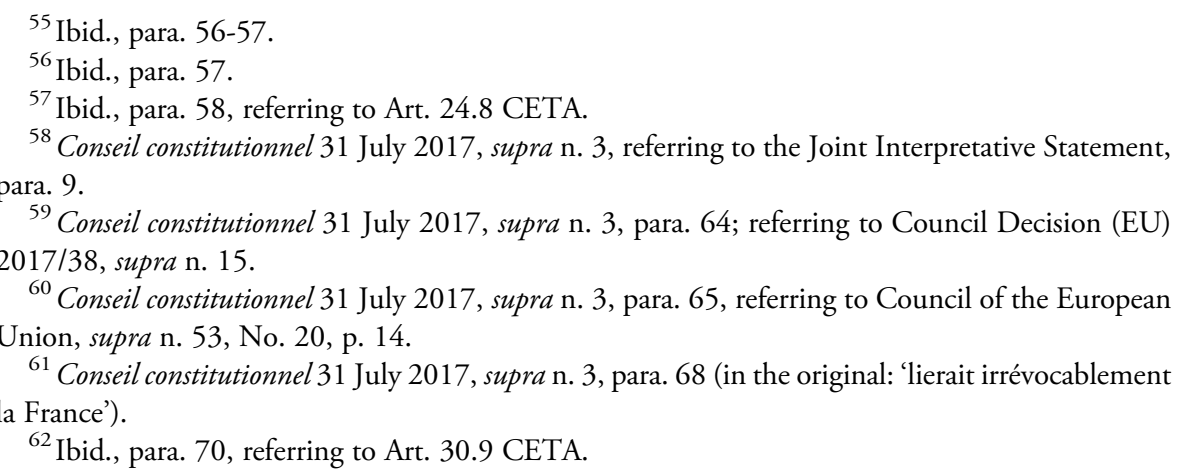


object and purpose, the agreement did not even touch upon any matters inherent to national sovereignty. ${ }^{63}$

In the remainder of the decision, the Conseil turned very briefly to the other provisions of CETA, i.e., those that fall within the EU's exclusive competence. The Conseil summarily ruled that since they did not violate any constitutional provisions, a fortiori no rules or principles inherent to France's constitutional identity were violated either. ${ }^{64}$ The Conseil constitutionnel concluded its decision by stating that, based on all the foregoing, CETA 'does not contain any provision contrary to the constitution'. ${ }^{65}$

\section{COMMENTS: FINE-TUNING DEFERENCE AT DIFFERENT LEVELS}

The decision of the Conseil constitutionnel essentially amounts to authorising ratification from a French constitutional point of view. The Conseil's approach can be described as going beyond mere rubberstamping, but refraining from deep scrutiny and leaving fewer strings attached than the Bundesverfassungsgericht did in its CETA ruling on the requested interim measures. ${ }^{66}$ Being a truly Kelsenian constitutional court - with several former leading French politicians on the bench, including Laurent Fabius, Valéry Giscard d'Estaing, and Lionel Jospin - supposed to temper legal rigidity with political acumen, ${ }^{67}$ the Conseil has by and large lived up to its mandate in this decision.

For the Conseil constitutionnel, the CETA decision was the 14th time it has been called upon to provide an a priori review of an international agreement. Before its decision on the Maastricht Treaty in 1992, the Conseil had not held any international agreement unconstitutional. ${ }^{68}$ Subsequently, the Conseil has found

${ }^{63}$ Conseil constitutionnel 31 July 2017, supra n. 3, para. 70.

${ }^{64}$ Ibid., para. 73.

${ }^{65}$ Ibid., para. 75 (in the original: 'ne comporte pas de clause contraire à la Constitution').

${ }^{66}$ Bundesverfassungsgericht 13 October 2016, supra $\mathrm{n}$. 4, in which, among other things, the German Federal Constitutional Court did not rule out the possibility that CETA may be at odds with German constitutional identity (paras. 50 and 59) and demanded that the Federal Government clarify and assert its interpretation of Germany's power to halt CETA's provisional application (para. 72).

${ }^{67}$ This political sensitivity appears even more pronounced in a priori review of treaties as compared to the review of legislation. For instance, former President Valéry Giscard d'Estaing refrains from taking part in priority preliminary rulings on the issue of constitutionality (questions prioritaires de constitutionnalité), but does sit on the bench when it concerns international agreements, such as CETA. Jacqué, supra n. 8, p. 240. See also M. Tushnet, Advanced Introduction to Comparative Constitutional Law (Edward Elgar 2014) p. 50; and F. Fabbrini, 'Kelsen in Paris: France's constitutional reform and the introduction of a posteriori constitutional review of legislation', 9 German Law Journal (2008) p. 1297.

${ }^{68}$ Conseil constitutionnel 9 April 1992, Décision n 92-308 DC, Traité sur l'Union européenne, ECLI:FR:CC:1992:92.308.DC. See also Claes, supra n. 19, p. 469. 
other international agreements, such as the Rome Statute establishing the International Criminal Court and the Lisbon Treaty, ${ }^{69}$ incompatible with the constitution and therefore requiring constitutional amendment.

Its task with regard to CETA was all the more challenging because, in both legal and political terms, it had to take the European level into account in addition to the French domestic level and, in turn, how the multilevel European constitutional order interacts with the outside world. In doing so, the Conseil constitutionnel drew on the full range of legally relevant documents including, in addition to the French constitution, other norms of its bloc de constitutionnalité, EU law, European Court of Justice case law, international law, as well as non-binding (soft) instruments such as the Joint Interpretative Statement and declarations issued by the EU Member States upon signing CETA.

The following comments, therefore, focus on the elements of Völkerrechtsfreundlichkeit ('friendliness towards international law') and Europarechtsfreundlichkeit ('friendliness towards European law') in the decision, arguing that overall the Conseil scored high on both counts, but that it could have been more specific and outspoken in the former case, and even more deferential in the latter.

\section{Völkerrechtsfreundlichkeit}

The Conseil constitutionnel has expressed a great deal of confidence in the French government, especially as regards the use of its treaty-making powers to conclude the new generation of trade agreements. This is overall to be welcomed, as too many hurdles and too intricate constitutional arrangements can easily stymie international action by the EU and its Member States, which together form a complex collective international actor. The 'Wallonia crisis' of late 2016 has amply demonstrated that, prompting further academic debate on how to hold governments accountable while still being able to bring Free Trade Agreement negotiations to fruition. ${ }^{70}$

\footnotetext{
${ }^{69}$ Conseil constitutionnel 22 January 1999, Décision n ${ }^{\circ} 98-408$ DC, Traité portant statut de la Cour pénale internationale, ECLI:FR:CC:1999:98.408.DC, and Conseil constitutionnel 20 December 2007, Décision n 2007-560 DC, Traité de Lisbonne modifiant le traité sur l'Union européenne et le traité instituant la Communauté européenne, ECLI:FR:CC:2007:2007.560.DC.

${ }^{70} \mathrm{See}$, on the one hand, the Namur Declaration, 5 December 2016, < declarationdenamur.eu/en/ index.php/namur-declaration/> visited 12 October 2017, which calls for more (but also more efficient) involvement of national and regional parliaments in the process, and on the other hand, the Trading Together Declaration, 25 January 2017, <https://docs.wixstatic.com/ugd/ 035467_d81f8a7835434c438cff38b5f20dd036.pdf> visited 12 October 2017, which highlights the existing democratic checks at the European level and calls for streamlining the process (e.g. by avoiding 'mixity' when possible).
} 
In its analysis, the Conseil constitutionnel manages to dispel some of the misconceptions pertaining to CETA and similar trade agreements still in the making. For instance, it emphasises in no uncertain terms that ultimate authority over the agreement lies with the parties in the Joint Committee, and that France in any event retains influence and control through the Council of the EU. It stresses that CETA's dispute settlement arrangements, including the Investment Court System, are governed by internationally approved judicial ethics standards and contain mechanisms to ensure impartiality and independence.

While the Investment Court System does provide an additional choice of legal remedy to Canadian investors in France (and the rest of the EU), the Conseil convincingly explains how this only amounts to a rather limited difference in treatment, which can be justified both at home (attracting investment) and abroad (opening up markets for French and other EU investors). It confirmed that CETA takes environmental and labour standards seriously, in particular through its chapter on sustainable development and the Joint Interpretative Statement with their explicit references to the right to regulate, which lend ample protection to constitutionally-enshrined principles such as the precautionary principle.

A point where the Conseil constitutionnel might have taken its cue from the Bundesverfassungsgericht's approach concerns the termination of provisional application and termination of the agreement, with which it could have engaged more fully. The Conseil rightly underlines that CETA explicitly provides for termination of the provisional application of the agreement as well as for termination of the agreement after its entry into force. In a bilateral (France and Canada) or non-mixed agreement with a third country (EU and Canada) such provisions on termination would have been clear from the point of view of international treaty law. However, given that CETA is a mixed agreement, the Conseil could have given more consideration to the position of Member States here, as highlighted by the complainants in their request.

The Conseil is right to point out that only the parts of CETA that fall within the EU's exclusive competence will be provisionally applied and to highlight the declaration made by the Council of the EU in this regard - a source that was not available at the time of the interim measures decision of the Bundesverfassungsgericht. However, the declaration only provides limited guidance here, specifying that when the EU-wide ratification process definitively fails, the 'necessary steps will be taken in accordance with EU procedures'. ${ }^{71}$ This would not seem to unequivocally support the right of a Member State to terminate provisional application unilaterally, as was asserted, for instance, by the German government before its own constitutional court. ${ }^{72}$ The Conseil constitutionnel

\footnotetext{
${ }^{71}$ Council of the European Union, supra n. 53, No. 20, p. 14.

${ }^{72}$ Bundesverfassungsgericht 13 October 2016, supra n. 4, para. 72. However, the German government seems to equivocate as regards such a right for unilateral termination of provisional
} 
could have admitted as much, and in the same breath recall that since only areas of EU-exclusive competence were concerned, the matter fell outside the scope of the ordinary compatibility review. As long as provisional application does not encroach upon France's constitutional identity, there is no need for a unilateral emergency break that could be triggered by the French government.

A need for greater clarity also applies to the constraints that the French government may face regarding the termination of the CETA after its entry into force. On this aspect, the Conseil should have been even less succinct and more detailed in its reasoning compared to its treatment of provisional application. As it rightly pointed out, CETA explicitly provides for termination. However, here the situation is distinctly more complicated than in the preceding area of provisional application. Being a mixed agreement covering areas of both exclusive and nonexclusive competences, it is not at all clear whether Member States would have a unilateral, absolute right of termination. On one hand, they are parties to the agreement. On the other, they are not empowered to denounce parts of an agreement for which they have transferred competences to the Union. Instead, the Conseil waves this complaint off by stating that, in light of its purpose, the agreement does not touch upon 'a domain inherent to national sovereignty'. ${ }^{73}$ This is contrary to the assessment of the Bundesverfassungsgericht, which was explicit about the possibility that CETA as a whole - once it enters into force in its entirety, including the chapter on investment - may be at odds with Germany's constitutional identity. With regard to both termination of provisional application and termination of the agreement, at the very least consultation with the EU institutions would be required as part of the duty of sincere cooperation discussed below - rather than giving the French government a completely free hand, as the Conseil seems to suggest.

Moreover, the decision might have benefited from an acknowledgement of the evolution - propelled also by the pressure of civil society organisations and sceptical governments - that CETA has undergone in its latest stages. It was easier to rule on judicial impartiality and independence, for instance, after the appellate

application in the declaration to the Council minutes it added together with Austria, see Council of the European Union, supra n. 53, No. 21, p. 14, where it both asserts 'rights which derive from Article 30.7(3)(c) of CETA' while also stressing that the 'necessary steps will be taken in accordance with EU procedures'. France did not attach any declaration in its own name. According to Van der Loo and Wessel, due to the fact that provisional application of a mixed agreement only covers matters of EU exclusive competence, 'only the Union (and not one or more Member States) can terminate the provisional application of the agreement': G. Van der Loo and R. Wessel, 'The nonratification of mixed agreements: Legal consequences and solutions', 54 Common Market Law Review (2017) p. 735 at p. 761.

${ }^{73}$ Conseil constitutionnel 31 July 2017, supra n. 3, para. 70 (in the original: 'un domaine inhérent à la souveraineté nationale'). 
tribunal was introduced following the 'legal review' (also known as 'legal scrubbing') of early 2016, which will be set up to correct decisions marred by legal flaws at first instance and will achieve better overall coherence in future CETA Investment Court System case law. Similarly, further clarification of the importance of the right to regulate, especially in the Joint Interpretative Statement, has helped in finding that CETA does not undo domestic legislative and regulatory powers. The two points are connected, since legally well-trained and impartial judges are bound to take cognisance of the strong textual and structural foundations of the right to regulate in adjudicating disputes involving CETA in the future. We will never know whether the original, 'pre-Wallonia crisis' version of CETA could have stood up to scrutiny by the Conseil constitutionnel, but CETA's revisions - tedious and frustrating as they seemed at the time - made its task easier. This beneficial exercise of contestation and refinement should not be forgotten.

As a whole, and arguably to its greatest credit, the decision serves to build on the Conseil's earlier case law sketching out a modern notion of sovereignty. The Conseil's use of the concept of conditions essentielles d'exercice de la souveraineté nationale is instructive here, showing that what was at issue was not any form of strict limitation of sovereignty, but rather the exercise of certain particularly important competences - core state functions - by organs other than those of the state, by virtue of a transfer of these competences to EU or international organs. ${ }^{74}$ There are limitations as to the extent and nature of such transfers, but these have to be put in context and construed narrowly, in a manner that provides a reasonable degree of leeway for the political branches. In this regard, it is important to recall that ever since its famous IVG decision, ${ }^{75}$ it is clear that the Conseil aims to maintain a limited review, i.e., review based on norms of the bloc de constitutionalité, but no review of whether a law or international agreement is in conformity with (other) international treaties already binding France. Concerning laws transposing EU law, the standard of review is even more restricted, given that participation in the EU and compliance with its laws is also a constitutionally enshrined requirement for France. ${ }^{76}$

\footnotetext{
${ }^{74}$ M. Troper, 'L'Europe politique et la souverainté des États', in S. Goyard-Fabre (ed.), L'État au XXe siècle: Regards sur la pensée juridique et politique du monde occidental (Vrin 2004) p. 181 at p. 188-189.

${ }^{75}$ Conseil constitutionnel 15 January 1975, Décision n ${ }^{\circ}$ 74-54 DC, Loi relative à l'interruption volontaire de la grossesse, ECLI:FR:CC:1975:74.54.DC.

${ }^{76}$ Conseil constitutionnel 10 June 2004, Décision $\mathrm{n}^{\circ} 2004-496$ DC, Loi pour la confiance dans l'économie numérique, ECLI:FR:CC:2004:2004.496.DC, para. 7, which references Art. 88-1 of the French constitution. See further A. Levade, 'La construction européenne et son incidence sur les compétences étatiques et la hiérarchie des normes', $\mathrm{n}^{\circ} 102$ Revue française de droit constitutionnel $(2015 / 2)$ p. 287 at p. $289-290$.
} 
In the CETA decision, the Conseil had to apply the concept of conditions essentielles d'exercice de la souveraineté nationale in the particularly intricate scenario of a mixed and 'new generation' Free Trade Agreement, i.e., a situation where both France and the EU - within which France already has pooled many of its state powers - would transfer competences to organs and mechanisms to be created by CETA, and within which they would operate side by side, alongside the other EU Member States and Canada. By keeping the constitutional limits narrow in this new context, it showed that 'sovereignty' must not be abused as a generic label used to declare illegal any measures and forms of collaboration that individuals or groups dislike for political or ideological reasons. Sovereignty is to be understood not in a static and zero-sum, but in a dynamic and cooperative way. Hence, the standard of conditions essentielles d'exercice de la souveraineté nationale as used here may also appeal to other constitutional courts in Europe and beyond, especially those wishing to confirm their respective countries' commitment to international cooperation on contemporary issues while protecting their sovereign prerogatives in a way that is more deferential than the Bundesverfassungsgerich's approach.

\section{Europarechtsfreundlichkeit}

Regarding the EU law aspects of the decision, the Conseil constitutionnel faced a formidable challenge in having to rule on the constitutional conformity of a mixed agreement without encroaching on the competences conferred upon the EU and the ultimate authority of the European Court of Justice to interpret EU law. This was achieved overall, also due to the use of the concept of conditions essentielles d'exercice de la souveraineté nationale mentioned above. However, there are certain problematic instances where the Conseil should have clarified some important points of EU law and deferred more emphatically to the EU institutions.

The demarcation of CETA into areas of exclusive EU competence and nonexclusive competences (shared or Member States-only) was an essential preliminary element of the decision. Hence, the Conseil constitutionnel could have chosen to raise this as a preliminary question at the European Court of Justice under Article 267 TFEU. ${ }^{77}$ Instead, the Conseil draws on the recently issued Opinion 2/15 of the European Court of Justice on a trade agreement with similar but not identical content. Regarding investment protection and the Investment Court System, Opinion 2/15 is arguably clear enough that these are non-exclusive competences. However, on the other provisions in a range of other chapters, the

\footnotetext{
${ }^{77}$ Since the Conseil constitutionnel is a court of last instance, one could even go so far as to speak of an obligation to request such an opinion under Art. 267, para. 3 TFEU, though in practice a court of last instance rarely heeds this obligation. Moreover, a problematic factor may have been the fact that CETA has not yet entered into force. Nonetheless, it could have raised questions of EU law in more general terms.
} 
Conseil at no point becomes very specific about why exactly they are shared. In Opinion 2/15, by contrast, the European Court of Justice made it clear that provisions in other chapter such as 'Objectives and General Definitions' and 'Institutional, General and Final Provisions' need to 'relate to the provisions' in the chapter on investment and 'to the extent that the latter fall within a competence shared between the European Union and the Member States. ${ }^{78}$

Nonetheless, although requesting a delimitation of competences from the European Court of Justice in the form of a preliminary reference could have clarified matters further, using Opinion 2/15 achieved judicial economy and expediency, and also showed the requisite deference to the European Court of Justice's prerogatives and the principle of conferral more generally. It is unlikely, moreover, that the European Court of Justice will deviate from its recent case law in Opinion 2/15 in its forthcoming opinion on CETA, as requested by Belgium.

A principle of EU law which the Conseil constitutionnel does not mention - but should have - is the duty of sincere cooperation enshrined in Article 4(3) TEU. This duty is particularly relevant in the context of mixed agreements, as emphasised by the European Court of Justice, ${ }^{79}$ which used it in the past as the textual basis for concluding that Member States have an obligation - not only under international law but also as a matter of EU law - to implement mixed agreements in their entirety. ${ }^{80}$ This notably includes elements falling within the sphere of competence of the Member States. Admittedly, this would only apply once an agreement enters into force and should not have bearing on the a priori constitutional compatibility review powers of the Conseil and other Member State courts. However, in its decision the Conseil may be seen as painting a picture of clearly delimited spheres of competence within which the responsibility to implement is incumbent upon either the EU or the Member States. This mischaracterises the composite nature of mixed agreements, the obligations under EU law to comply with them in their entirety, as well as the requirement of paying due consideration and, if necessary, deference to Union positions and interests. Consequently, a clear reference to the duty of sincere cooperation - perhaps construed as the TEU's echo of the French constitution's call to participation in the EU as expressed in Article 88-1 - would have been welcome.

The final part of the decision is also quite striking, when the Conseil wraps up its reasoning by turning its attention to the parts of CETA that fall under the exclusive competence of the EU. Earlier in the decision, it had reiterated its stance

\footnotetext{
${ }^{78}$ EU-Singapore FTA, supra n. 5, para. 305.

${ }^{79}$ See, e.g., ECJ 15 November 1994, ECLI:EU:C:1994:384, Opinion 1/94 (WTO), para. 108; and further C. Hillion, 'Mixity and coherence in EU External Relations: The significance of the "duty of cooperation"', in C. Hillion and P. Koutrakos (eds.), Mixed Agreements Revisited: The EU and its Member States in the World (Hart Publishing 2010) p. 87.

${ }^{80}$ ECJ 19 March 2002, ECLI:EU:C:2002:184, Commission v Ireland (Berne Convention).
} 
that it would only exercise marginal review of compatibility with French constitutional identity as the standard for these areas. This dovetails with Article 4(2) TEU, where the EU commits to respect the Member States' constitutional identity. However, the Conseil avoided making this link explicit by referencing it (nor did the Bundesverfassungsgericht for that matter).

What the Conseil subsequently did is arguably an exercise of perhaps wellmeaning yet misplaced judicial economy. It ruled that since the other provisions of CETA are not at odds with French constitutional law, they cannot be, a fortiori, at odds with its constitutional identity. Its reasoning ends there. This is succinct but problematic. In line with the Conseil's own differentiation of review standards, it should never have expressed itself on the constitutionality tout court of CETA provisions falling under the EU's exclusive competence. This is - according to its own distinction of standards of review - not within its power. As it correctly states earlier on in the decision, it would only be for the European Court of Justice to determine whether these provisions conform with EU primary law. Following Belgium's request for an opinion, the European Court of Justice now has an opportunity to do exactly that.

Lastly, this summary reasoning was also a missed opportunity to learn more about the content of France's constitutional identity and its application in an international context. From judgments and scholarship across Europe, we know already that this is supposed to be a very narrow sub-category of constitutional law. ${ }^{81}$ However, to date is has only been addressed by the Conseil in cases concerning laws transposing EU directives. ${ }^{82}$ It would have been interesting to learn whether the new context of mixed agreements had any impact on the Conseil's interpretation of the concept. Since the Conseil makes it clear that nothing of what is contained in CETA raises any conflicts, it might at least be implied that constitutional identity remains narrowly construed. Nonetheless, a few more sentences explaining where we need to look for expressions of French constitutional identity within the bloc de constitutionnalité, and which principles of constitutional identity might have been at issue here, would have been welcome, also with a view to EU law in terms of giving substance to the scope of Article 4(2) TEU.

Nonetheless, while this would have provided useful obiter for academic purposes and possible future litigation, the Conseil constitutionnel pays close

\footnotetext{
${ }^{81}$ See, seminally, F.-X. Millet, L’Union européenne et l'identité constitutionnelle des États membres (L.G.D.J. 2013); E. Kloots, National Identity in EU Law (Oxford University Press 2015); and A. von Bogdandy and S. Schill, 'Overcoming Absolute Primacy: Respect for national identity under the Lisbon Treaty', 48 Common Market Law Review (2011) p. 1417.

${ }^{82}$ See, from the more recent case law, Conseil constitutionnel 3 February 2016, Décision n ${ }^{\circ} 2015-$ 520 QPC, Société Metro Holding France SA venant aux droits de la société CRFP Cash, ECLI:FR: CC:2016:2015.520.QPC.
} 
attention overall to both the prerogatives of the European Court of Justice, and although mostly implicitly - to the prerogatives of the EU institutions in making CETA work.

\section{ConClusion}

Having summarised and analysed the decision of the Conseil constitutionnel on the constitutionality of CETA, three main conclusions can be drawn. First, the decision is another enlightening exercise of dynamic multilevel constitutionalism within the EU with a distinctly external outlook. The decision illustrates the evolving content of CETA and needs to be seen as part of the ongoing judicial scrutiny by various courts. Civil society pressures led to significant changes to CETA, many of which are repeatedly highlighted by the Conseil in finding that there is no constitutional conflict. The Joint Interpretative Statement and declarations added to the Council minutes help to clarify matters further, in a way that was not available to the Bundesverfassungsgericht earlier. The European Court of Justice's opinion on CETA will be the next step in this evolving saga, and it will be interesting to observe the extent to which it pays homage to national courts in its reasoning as part of the ongoing process of judicial dialogue.

Second, the decision prompts further reflection on the scope and content of the Member States' constitutional identity. In this regard, the decision is a missed opportunity since it tells us very little about the content of France's identité constitutionnelle. Only in the negative sense: we now know that nothing in CETA is at odds with it, confirming the general impression that is a very limited category. It may also serve as a reminder that Article 4(2) TEU provides only an outer limit of the core of national law that European integration cannot touch, and that each Member State has a different constitutional identity, which may be more or less extensive.

Third, and most importantly, the decision of the Conseil constitutionnel illustrates that cases such as these are extremely demanding as they require that courts balance their duty to protect the constitution with their duty to respect EU law as well as to pay due consideration to international political realities. The Conseil constitutionnel, despite some points that could have been clarified as discussed above, fared well in reconciling these different imperatives - not least due to its dynamic construction of the notion of conditions essentielles d'exercice de la souveraineté nationale. In particular, it shows commensurate deference to the political branches, both at the national and European levels, to engage internationally with like-minded countries on contemporary issues of international economic governance, thereby underwriting the EU's ability to act despite being a complex collective international actor with different levels of judicial and democratic safeguards. 